\title{
HURON-WENDAT ARCHAEOLOGICAL HERITAGE: BUILDING RELATIONSHIPS TOWARDS COLLABORATION
}

\author{
Patrimônio arqueológico Huron-Wendat: \\ construindo relações para a colaboração
}

\author{
Alicia L. Hawkins* \\ Louis Lesage**
}

\begin{abstract}
There is a long history of academic interest in the Huron-Wendat people of the seventeenth century in Ontario. Despite this interest, archaeologists and other academics have only recently begun to engage with the Huron-Wendat community regarding excavations of Huron-Wendat sites in Ontario. This engagement is a first step, and it does not represent true collaboration, because in most cases investigations are not partnerships and do not arise from questions posed by members of the Nation. In 2015, to mark the four-hundredth anniversary of the arrival of Champlain in Ontario, members of the Huron-Wendat Nation and archaeologists co-organized a conference focussed on subjects of interest to the Nation, including their relationship with the "St. Lawrence Iroquoians," Wendat and Wyandot history after 1650, and bioarchaeological analyses. This paper presents a brief history of archaeological research on the Huron-Wendat past and outlines some new, more collaborative avenues of present and future research.
\end{abstract}

Keywords: Huron-Wendat Nation, collaborative archaeology, Ontario

* School of the Environment. Laurentian University. Sudbury, ON Canada. +1-705675-1151. ahawkins@laurentian.ca

** Bureau Niowentsïo. Nation huronne-wendat. 255, place Chef Michel Laveau. Wendake, QC Canada. +1-418-843-3767. louis.lesage@cnhw.qc.ca 


\section{RÉSUMÉ}

L'intérêt universitaire pour la population Huron-Wendat du dixseptième siècle en Ontario est loin d'être nouveau. Malgré cela, ce n'est que très récemment que les archéologues et autres chercheurs travaillent avec la communauté Huron-Wendat autour des excavations de sites Huron-Wendat en Ontario. Cette implication est un premier pas, mais ne peut être vue comme une réelle collaboration car dans la plupart des cas les investigations ne sont pas des partenariats et ne répondent pas à de questions directement posées par les membres de la Nation. En 2015, pour le quatre-centième anniversaire de l'arrivée de Champlain en Ontario, les membres de la Nation Huron-Wendat et des archéologues ont co-organisé un colloque autour de sujets significatifs pour la nation, parmi lesquels la relation avec les « Iroquoiens du Saint-Laurent », les Wendat et l'histoire Wyandot après 1650, ainsi que les analyses bio-archéologiques. Cet article présente une brève histoire de la recherche archéologique sur le passé Huron-Wendat et dégage de nouvelles et plus collaboratives voies de recherche présentes et à venir.

Mots-clés: Nation Huron-Wendat; archéologie collaborative; Ontario

\section{RESUMO}

Existe uma história longa de estudo acadêmico do povo HuronWendat no século dezessete no Ontario. Apesar disso, é muito recente o engajamento dos arqueólogos e de outros acadêmicos com a comunidade Huron-Wendat em relação às escavações de sítios Huron-Wendat no Ontario. Este engajamento constitui um primeiro passo, porém não representa uma verdadeira colaboração considerando que na maioria dos casos as investigações não são parcerias e não se baseiam em perguntas diretamente formuladas pelos membros da Nação. Em 2015, para marcar o aniversario de quatrocentos anos da chegada de Champlain no Ontario, membros da Nação Huron-Wendat e arqueólogos co-organizaram um colóquio sobre temas de grande interesse para a Nação, incluindo a relação com os "St. Lawrence Iroquoians," os Wendat e a história dos Wyandot depois de 1650, assim como análises bio-arqueológicas. Este artigo apresenta uma breve história da pesquisa arqueológica sobre o passado dos Huron-Wendat e revela alguns novos, e mais colaborativos, caminhos de pesquisas presentes e futuras.

Palavras-chave: Nação Huron-Wendat; arqueologia colaborativa; Ontario 
Collaborative indigenous archaeology is fundamentally about making better histories, better sciences, and better communities.

- Stephen Silliman, Collaborative Indigenous Archaeology: Troweling at the Edges, Eyeing the Centre

\section{Situating Research on the Huron-Wendat}

Four hundred years ago, when Samuel de Champlain visited some parts of Ontario, ancestors of people who call themselves Huron-Wendat and Wyandot ${ }^{1}$ occupied, notably, the lands on the southern part of Georgian Bay, referred to now as the region of northern Simcoe County (Biggar, 1936). At that time, they formed a confederacy made up of several Nations of different sizes who, according to oral tradition, had arrived in the area at different times during the previous several centuries (Sioui, 1999; Tooker, 1991). Archaeological and oral history suggests that some of the HuronWendat had previously lived in the St. Lawrence valley, in presentday Québec (Ramsden, 2016b; Richard, 2016; Warrick, 2008).

Between 1615 and 1649, French traders and missionaries lived among the Huron-Wendat, establishing both a special-purpose

1 Several different ethno-linguistic terms are used in this paper. The term Huron comes from the French and is a pejorative term, but was widely used by ethnographers, historians and archaeologists until the late twentieth century. The term Wendat is the self-appellation used in the 17 th century. Petun is the term applied by Europeans to people from the Collingwood area; in this case the self-appellation is Tionnontaté. Attawandaron is a term that the Huron-Wendat people assigned to their Iroquoian-speaking neighbours in southwestern Ontario. Wyandot(te) is the selfappellation of peoples who moved westwards in the mid-seventeenth century and eventually settled in Detroit/Windsor, Okhahoma and Kansas.

In this paper, except when referring to specific work by previous researchers, we use the term Huron-Wendat as an encompassing one that refers to the Iroquoian peoples who lived in what is known today as southern Ontario in the early time of New France, spoke the same language, and identified as "Wendat" (i.e., the Huron and the Petun/Tionnontaté). The Conseil de la Nation huronne-wendat does not believe that the distinction made by Champlain and the Jesuits between the Huron and the Petun/Tionnontate reflected actual ethnic differences and considers both groups and their descendants (i.e., the Huron-Wendat and Wyandot nations) to be Huron-Wendat. When referring specifically to the contemporary community of Wendake, the term Nation huronne-wendat (Huron-Wendat Nation) is privileged. 
mission site (Sainte-Marie among the Hurons) and a number of missions within Wendat villages (Thwaites 1896-1901). In Canada, this was one of the most focussed, sustained, and earliest efforts to convert an Indigenous population to Christianity (Blackburn, 2000). The relationship between the French and the Huron-Wendat was multifaceted, however, with trade and alliance building also being important (Blackburn, 2000; Trigger, 1976). Champlain (Biggar, 1936), Sagard (1939), and the Jesuits (Thwaites 1896-1901) chronicled their time among the Huron-Wendat. Their works, each of which reflects the different purposes and perspectives of the authors (Tooker, 1991), provide us with insight on seventeenth-century French perspectives about their lives among their Huron-Wendat hosts. By the 1630s, the European presence in Huron-Wendat communities led to the introduction of several waves of different European-introduced disease, causing major population decline (Warrick, 2003). After struggling for some years and facing conflict from Haudenosaunee peoples, in 1649, the Wendat people left what is now Simcoe County and decided to move in several different directions (Labelle, 2013).

Figure 1

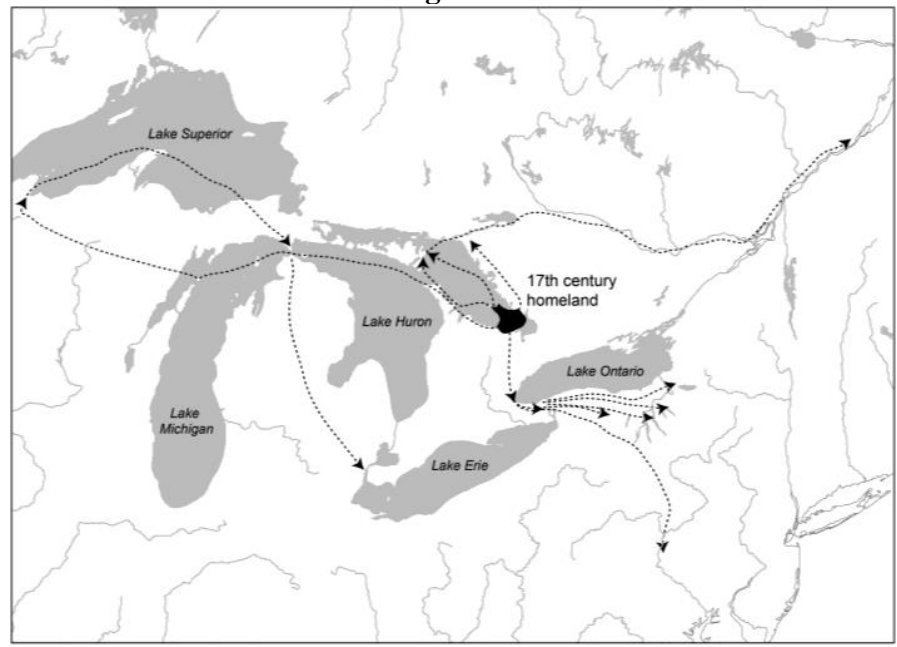

Location of the seventeenth-century Wendat confederacy and locations of movement, after Trigger (1976: 822). 
The seventeenth-century ethnohistoric documents provided rich fodder for non-Huron-Wendat scholars. Historians, anthropologists, and geographers built their reputations and credibility upon interpretations of these seventeenth-century works. In the 1960s and 1970s, several important books synthesized Wendat life in the seventeenth century from different perspectives. Notably, Elisabeth Tooker's work An ethnography of the Huron Indians, 1615-1649 (Tooker, [1964 ]1991), Conrad Heidenreich's Huronia (Heidenreich, 1971), and several of Bruce Trigger's books (Trigger, 1976, 1990) were read and cited widely. Innumerable undergraduate students read Trigger's short work The Huron: Farmers of the North, which was published in a series entitled Case Studies in Cultural Anthropology. Today, it is gratifying to see a shift towards Heritage of the Circle, by Huron-Wendat historian Georges Sioui (1999).

While longer works by Trigger were historical in nature, and notwithstanding the specific date range for Tooker's work, it can be argued that the rich ethnohistoric record, and the synthetic works based on them, led to a situation in which "Huron-Wendat" became synonymous with the Huron-Wendat of the early to mid-seventeenth century as viewed and interpreted by European missionaries; traders; and, at a later date, scholars. These works examine the first half of the seventeenth century and are clearly situated in Ontario. Ramsden (1996) argues that this record has been a detriment to Wendat archaeology.

That the Huron-Wendat lived on after leaving Simcoe County appeared, unfortunately, to be of little academic interest, and despite the well-known work of ethnographer and linguist Marius Barbeau (1915, 1960), conducted in 1911-1912, by the late twentieth century, it had become commonplace to assert that the Huron-Wendat had been destroyed (Labelle, 2013) (Figures 2 and 3). Johnston and Jackson (1980, p. 173), for example, begin their paper on the Le Caron site by stating "Although the Huron were destroyed in the middle of the $17^{\text {th }}$ century by their traditional enemies, the Five Nations Iroquois of New York..." We attribute this situation to three different but related phenomena. 


\section{Figure 2}

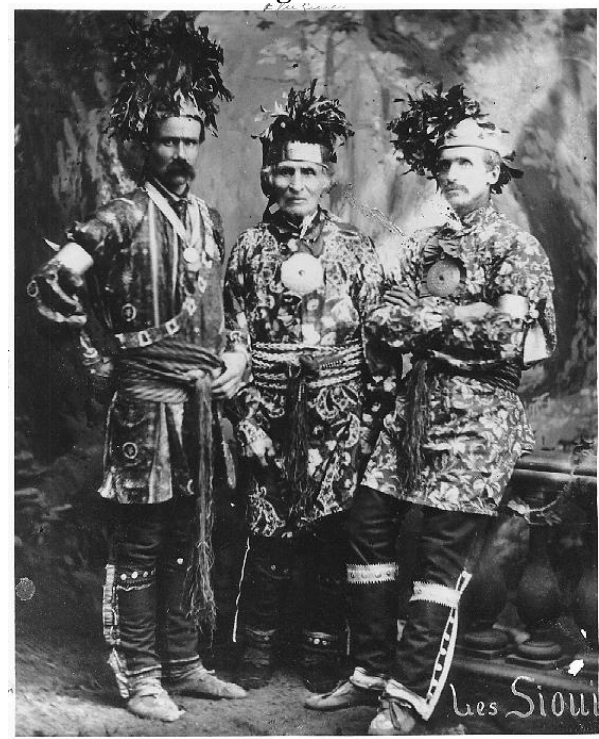

The Huron-Wendat who were NOT destroyed. A studio photograph from about 1880 of three Sioui family members. In the center Élie (1798-1884) flanked by his two sons Honoré et, Élie Junior. Photograph from the National Archives of Quebec.

Figure 3

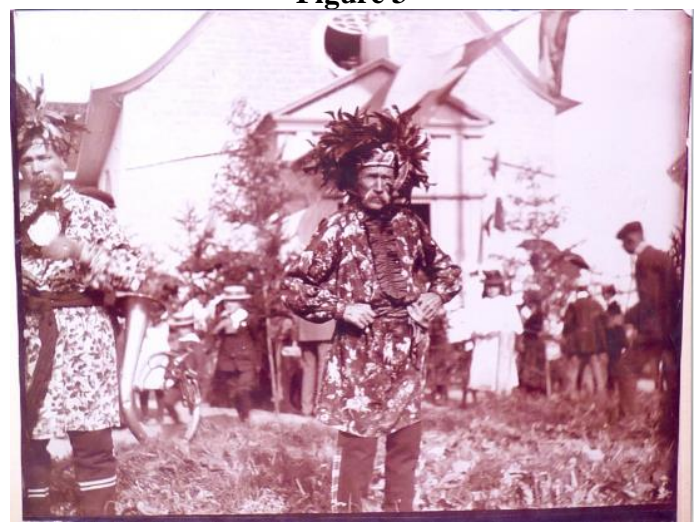

A Huron-Wendat elder during a festival in from of the chapel at Wendake. Circa 1900-1910. 
First, because of the major academic works based on seventeenth-century documents, the image of the Huron-Wendat in the minds of researchers crystallized as the "Farmers of the North."

Second, there was little anthropological interest in the HuronWendat of the twentieth century. The exact reasons for disinterest in the "survivors" are unclear, but factors that may be relevant are that Wendake was then seen as a small, "Canadianized" village, with "Euro-Canadian" architecture, where some members of the community had adopted Catholicism and where the economy was based in large part on commerce. Descendants seemed to conform to a "Canadianized" image rather than the "brave and courageous Indian" popular image and, thus, garnered little attention and research interest. In other words, an earlier anthropology that was defined as filling the "savage slot" (Cobb, 2005) would not take as a subject something that did not conform well to the category of "Other." By contrast, the Wendat of the seventeenth century or earlier were exemplars of a "pre-Columbian Other" and fit well within the scope of study.

Third, the story of a flourishing civilisation where villages of thousands of people prosperously directed commercial and diplomatic missions, and which collapsed in the face of wars and epidemics, represents a strong, dramatic, Hollywood-style image imprinted in the subconscious of Canadian people.

Archaeologists, who are traditionally concerned with material aspects of culture, may have lacked the will or imagination to seek connections between living Wendat and the traces of their ancestors found on archaeological sites. We argue that this lack of anthropological interest led outsiders to assume that the HuronWendat had suffered "cultural loss" and were disconnected from their past. Geographical and linguistic challenges also faced archaeologists or anthropologists from the English speaking world who may have wished to engage with Huron-Wendat descendants living in a Frenchspeaking environment. 


\section{Archaeological Research on the Huron-Wendat in Ontario}

In 2001, the renowned scholar Bruce Trigger wrote:

I hope that in the near future one or more Wendat professional archaeologists will be exploring their homeland along-side Euro-Canadian colleagues. Even before that happens, however, Wendat interests and concerns should have begun to influence Wendat archaeology by encouraging archaeologists to investigate questions that are of special interest to modern Wendats (Trigger, 2001, p. 10).

The history of the archaeology of Wendat sites is clearly rooted in Canada's colonial past, as are many investigations of Indigenous sites in other regions of the world (Atalay, 2006; Trigger, 1984). We argue that, despite recent advances, we have not yet managed to shed this legacy.

Investigation of Huron-Wendat sites has a particularly long history. Trigger $(1985$, p. 9) identifies nineteenth-century research of seventeenth-mission sites as among the earliest archaeological research in Canada. Initially interest came from Jesuits who wished to identify and describe the locations of their missions (Jones, 1908). However, these people also excavated numerous Huron-Wendat ossuaries (communal burials), demonstrating interests extending beyond Jesuit history (Trigger, 1985). Unfortunately, much of the nineteenth-century work was never published, and there are few remaining records of it (Kapches, 2014; Trigger, 1985). This time also saw major land clearance for farming and, in some locations, urban development, resulting in the accidental exposure of numerous villages and ossuaries. By the nineteenth century, the Huron-Wendat cultural landscape of the 1600s and earlier had been transformed into "wilderness," and European settlers accidentally discovered evidence of the traces of the Huron-Wendat taskscape (Dent, 2013). Andrew 
Hunter's (e.g., 1899, 1902,1904, 1907a, 1907b) surveys at the end of that century and the beginning of the twentieth century recorded this Huron-Wendat landscape in the form of numerous site locations; according to Trigger (2001), these surveys were remarkable in that they aimed to examine where the Wendat had lived (i.e., they were an early form of landscape archaeology).

These two themes, examination of the European presence and general survey of the region, continued well into the twentieth century. The first is best exemplified by the work of Kidd (1949) at Ste. Marie I and of the Jurys, also at Ste. Marie I, but also at other possible mission sites (Jury, 1946; Jury \& Jury, 1954, 1955). The second type of work, survey, was conducted in large part by Frank Ridley, an avocational archaeologist trained by Kidd, who also engaged in an attempt to relocate sites described historically (Ridley, 1947). However, the bulk of his work can be considered an extension of the surveys by Hunter, in which Ridley relocated and undertook small excavations at many of the Hunter sites, the main goal of which appears to have been refining initial interpretations of the site's chronologies (e.g., Ridley, 1975, 1973, 1972).

In the mid-twentieth century, a third theme emerged in Huron-Wendat archaeology: the use of Huron-Wendat sites as locations for university field courses. This began with the work of Emerson (University of Toronto) at Warminster, but later included the very long-lived excavations led by Knight at Ball (Wilfrid Laurier University), the excavations by Latta (University of Toronto) at Auger and Thomson Walker, by Johnston (Trent University) (Johnston \& Jackson, 1980) at Le Caron, by Glencross and Warrick (Wilfrid Laurier) at Ahatsistari, and by Hawkins (Laurentian University) at Ellery. While field schools may have research goals, their primary purposes, at least in the moment of excavation, are pedagogical. Work at Warminster, for example, investigated the possibility that this was the location of the village of Caihague, where Champlain had wintered in 1615. Artifact collections produced by field schools are typically housed within universities, and have therefore served as research materials for many later students. Field schools may adopt methodologies reflective of current practice within the discipline, or they may attempt to set higher standards of practice (Glencross et al., 2017). 
Discovery and excavation of sites outside of Simcoe County led to the realization that the ancestors of the Huron-Wendat had a geographical distribution that was much larger than the small area in northern Simcoe County where they were documented in the seventeenth century. Trigger (2001) has identified the themes and debates in these works, some of which were clearly influenced by the assumptions and/or theoretical backgrounds of the researchers themselves and appear to have little grounding in archaeological evidence. Ferris (2014) illustrates this with the case of the "conquest theory," which, in Wright's (1992) formulation, explains changes in pottery style by means of a kind of ethnic cleansing.

Major changes to the practice of archaeology in the province of Ontario occurred in 1975, with the introduction of the Ontario Heritage $A c t^{2}$ and the licensing of archaeological fieldwork. Rescue excavations had occurred previous to this, and initially these were funded by museums - a situation that clearly was not sustainable. The first "cultural resource management" firm was founded in the early 1970s, and major rescue excavations at the Draper site, a Wendat site on the north shore of Lake Ontario, was a de facto training ground for many of the people who would go on to be major players in the industry from the 1980s until the present. Over the course of the twentieth century, archaeology as a discipline in Ontario moved from the domain of academics and hobbyists to that of professionals working under a number of different legislative parameters. Today, close to 500 people are licensed to practice archaeology in Ontario, and many more people work under the supervision of these licensees. The vast majority of the archaeological work licensees do is "consulting" in nature or is compliance archaeology (98\% according to James Sherratt of Ontario's Ministry of Tourism, Culture and Sport, personal communication, 2016). Interestingly, many licensed Ontario archaeologists undertook training or research on HuronWendat archaeological sites as part of their studies. A group of Huron-Wendat youth from Wendake participated in excavations at the the Kondiaronk site in Ontario in 1979 (Fig. 2), but the Huron-

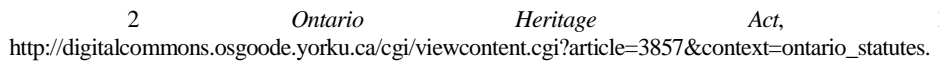


Wendat participation in management of archaeological sites in Ontario did not occur until the 2000s.

\section{Figure 4}

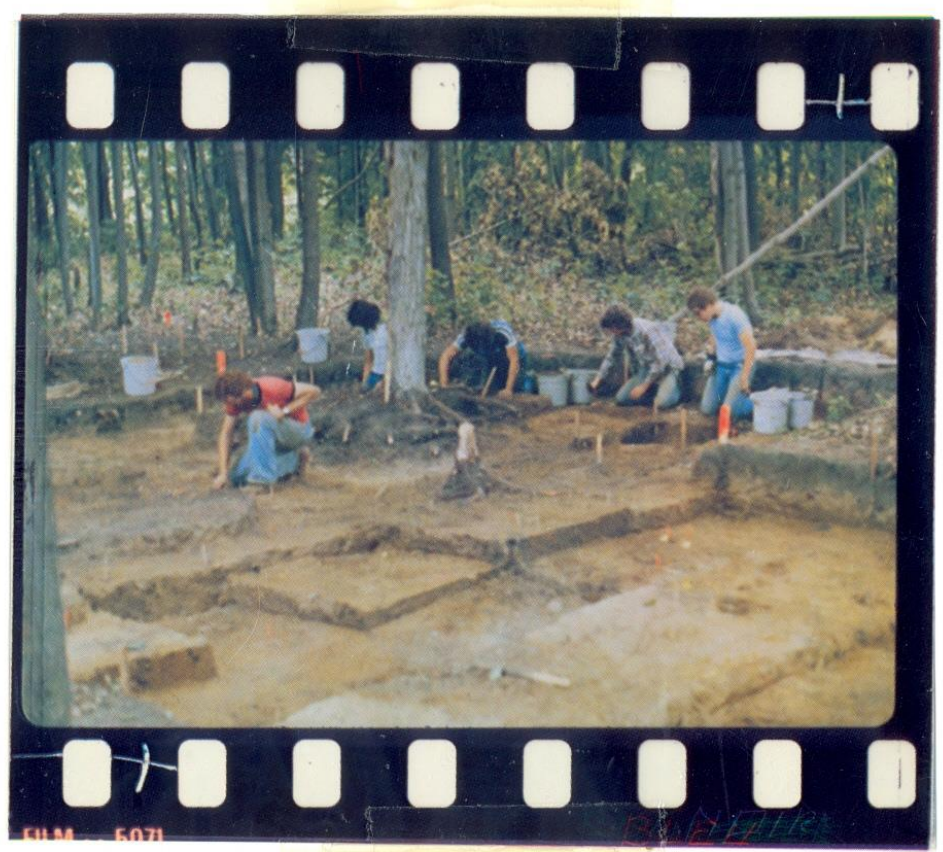

The Kondiaronk Site. From left to right: Raymond Sioui, Carlo Gros Louis, Christian Sioui, Don Sioui \& René Picard. July1979.

Recent Supreme Court decisions in Canada have made it clear that the Crown (which, in the case of Canada, refers to both the federal and provincial governments) is required to consult with First Nations on projects where Aboriginal and Treaty rights are at stake (MacCallum Fraser \& Viswanathan, 2013). Prior to that, in the early 2000s, the Huron-Wendat Nation was one of the First Nations who came together to form the Founding First Nations Circle (Nahrgang, 2013). This group was comprised of legal representatives of a number 
of First Nations with interests in the archaeological cultural heritage of southern Ontario. Because the heritage of this region is shared, with different groups present at different times and with overlapping traditional use areas, the Circle provided an opportunity for shared protection and stewardship.

By 2011, the ministry responsible for archaeology in Ontario (at that time called the Ministry of Tourism and Culture) published a document entitled Engaging Aboriginal Communities in Archaeology: A Draft Technical Bulletin for Consultant Archaeologists in Ontario. Directed only at archaeologists carrying out compliance archaeology, it defines engagement as "involving Aboriginal communities in each stage of an archaeological project, to the extent and in the manner that best suits their interests and the needs of the project" (Ministry of Tourism and Culture, 2011a, p. 1). It is unfortunate that the Ontario government did not require all licensed archaeologist to engage with First Nations. However, given that the vast majority of archaeology carried out in the province is consulting in nature (as opposed to academic, public, or avocational), this requirement may be viewed as generally positive in that most archaeologists are mandated to engage. However, the requirements only insist upon engagement relatively late in a project, that is, at "Stage 3," when sites have been identified and the archaeologist embarks on further investigation to determine cultural affiliation, site size, and temporal placement. The requirements thereby imply that the only places within a landscape that would have heritage value would be ones where there are identifiable physical remains in the form of archaeological artifacts. Clearly this is not the case (Colwell, 2016).

We do not view this engagement process as collaborative. It is reactive: when development has the potential to impact treaty rights, government insists upon dialogue with the First Nations determined to be culturally or geographically closest (Hiawatha v. Ontario 2007, Ministry of Culture 2011). This situation clearly represents a unique phenomenon in Canada: there are a very large number of Huron-Wendat archaeological sites and locations of cultural importance in Ontario, and the authority that should be engaged in a dialogue about this heritage (i.e. the Band Council) is in Québec. Hope for a better dialogue has yet to be formalized. 
Two common outcomes of engagement are the presence of First Nations monitors on archaeological sites during survey or excavation and suggestions to redirect proposed development away from archaeological sites. While these outcomes are an improvement upon a situation in which First Nations were never engaged, the discussions between Indigenous people and archaeologists that occur in this context only pertain to landscapes potentially impacted by development interests. They do not ask the questions "Can archaeology contribute to addressing questions of interest to Indigenous peoples? And if so, what are best practices for doing so?"

\section{New Directions}

In 2015, the Huron-Wendat Nation hosted a session at the annual symposium of the Ontario Archaeological Society ${ }^{3}$. Representatives of the Nation proposed the session topics and speakers, and they participated in applications for funding that would ultimately allow a large number of Wendat and Wyandot participants to travel to Ontario to participate in the conference. Other sessions at the conference were organized in partnership with the Nation. One of the components of the conference was that we asked Wendat and Wyandot representatives in attendance to identify papers of particular interest, so that they could be written up for publication on the Web. This provided us with insights about Wendat and Wyandot concerns and viewpoints. In the remainder of this paper, we outline three of the themes that came out of this conference and which indicate potential avenues of research and collaboration for Wendat and Wyandot, archaeologists, historians, linguists, biological anthropologists, and other researchers. Successful models for collaborative projects involving First Nations and academic researchers exist (e.g.,

3 The symposium was a joint event of the Ontario Archaeological Society and the Eastern States Archaeological Federation, but the organizing and program committees were comprised of members of the OAS only. 
Edmunds et al., 2013; IPinch, 2016), and these demonstrate the importance of involvement of all parties from the inception of the project. Open communication will allow researchers to come to understand not only what questions are of importance to the community, but also how community members can be involved in the process throughout the research project. Collaborative projects are reflexive, with modifications to the methodologies and/or questions arising through the process of dialogue.

\section{St. Lawrence Iroquoians and the Huron-Wendat}

A subject of fundamental interest to the Huron-Wendat is the archaeological entity or construct known as "St. Lawrence Iroquoians" (SLI). When Cartier arrived in the Gaspé in 1534, he encountered a group of Iroquoian-speaking people led by the chief Donnacona, who were there for fishing and seal hunting (Trigger, 1976). Cartier's travels in 1535 and 1536 brought him to the area of present-day Québec City, where Donnacona's people were living in the unpalisaded village of Stadacona. Cartier also visited the Montréal area, where a people were settled in a single, large, palisaded village called Hochelaga. Cartier documented approximately five other Iroquoian villages lying between Stadacona and Hochelaga. Starting six years later, in 1541, and continuing until 1543, the French attempted and failed to establish a colony in the area of Québec City at what is now known as the Cartier-Roberval site. When the French returned to the region in 1603, they found these villages abandoned (Biggar, 1936).

Archaeologists traditionally have framed this in terms of a "disappearance" and have sought explanations for this the "mystery" of where the St. Lawrence Iroquoians went. Causes that have been proposed include: European-introduced disease; warfare; environmental change, causing agriculture to be untenable in the area; and changes in trade routes (see Trigger 1976, p. 214-218, and TREMBLAY 2006, p. 118-121, for examples of the range of 
explanations). Over time, archaeologists described a set of artefact types common on sites in the St. Lawrence valley, including, most notably, pottery of particular styles (e.g., Jamieson 1990). An archaeological construct ("St. Lawrence Iroquoians") came to represent the people encountered by Cartier. "St. Lawrence Iroquoian" can be defined by particular pottery motifs, styles of pipes, and bone and stone tool forms (Jamieson, 1990). Furthermore, the attributes of this constellation of materials differ in small ways from the attributes of similar materials found on Ontario sites attributed to the Wendat and the Attawandaron. This led archaeologists to conclude that the Wendat were a different ethno-political group from the people Cartier encountered in the St. Lawrence valley in the sixteenth century.

Various items of research presented at the conference showed archaeological evidence of the presence of "St. Lawrence Iroquoian" artifacts in Huron-Wendat villages (Ramsden, 2016; Williamson, 2016). These artifacts can also be interpreted as evidence that people using the St. Lawrence valley (Gates St-Pierre, 2016) were also present in Ontario west of the St. Lawrence valley, in an area that is more commonly considered to have been territory of the HuronWendat. Linguistic similarities between Huron-Wendat and St. Lawrence Iroquoian were also presented (Steckley 2012, 2016). Finally, research presented at the conference by Marianne Gaudreau and Louis Lesage (Gaudreau and Lesage 2016), and other research published by Richard (2016), demonstrates other indications of a close relationship between the peoples occupying these areas.

The Huron-Wendat assert that they are the same people as the St. Lawrence Iroquoians. This is not new idea, but can be found in multiple historical documents and oral tradition (Gaudreau and Lesage 2016, Richard 2016). This assertion presents a significant but not insurmountable challenge to archaeologists' understanding of the past, mainly because archaeologists have come to conflate ethnic identities and archaeological constructs.

It is important to decouple Huron-Wendat identity or ethnicity from the Huron-Wendat political entity of the seventeenth century as recorded by French explorers and missionaries. The confederacy was something that existed for a period of time under socio-political circumstances that will probably never be explained in 
detail. On the other hand, Huron-Wendat ethnic identity both predates and post-dates the seventeenth-century confederacy.

Material culture and ethnic identity should not be expected to align perfectly. Gaudreau and Lesage point out that "ethnicity... is understood as a large-scale social group identity founded on a real or assumed shared belief in a common ancestry, and involves a process of self-identification" (Gaudreau and Lesage 2016, p. 9). Archaeologists, without access to belief systems, are hard pressed to define or delineate ethnic groups. In light of this, while there are distinctive attributes of the material culture of the St. Lawrence valley in the sixteenth century, we cannot take this to mean that the people of the St. Lawrence valley were distinct ethnically from Iroquoians living farther west, including in Ontario.

Warrick and Lesage (2016, p. 139) point out that archaeological data and subsequent interpretations are stronger in some areas than in others. They argue that archaeology can make meaningful contributions to interpretations about technology, economy, and settlement patterns but that things like ethnicity and religion are more difficult for archaeologists to reconstruct. They reiterate the position of Chrisomalis and Trigger (2004) who indicate that archaeologists are not qualified to make pronouncements on the ethnic identity of past contemporary Indigenous peoples. Rather, "Indigenous people know best who they are and where they come from" (Warrick and Lesage, 2016, p. 139).

\section{Post-relocation Huron-Wendat and Wyandot}

As we have already described, in the mid-seventeenth century the Huron-Wendat left the Simcoe County area. The people who made up the confederacy made choices to pursue different alliances in light of the difficulties in Ontario. In several waves, Wendat arrived in the St. Lawrence valley area (mainly the Québec City area) - an area of traditional importance and with which many were familiar because of trade in earlier the century. Others joined the 
Tionnontaté, and eventually the Odawa, through the second half of the seventeenth century. These people lived in a number of communities in the Upper Great Lakes region, and their descendants are found in Wyandot communities in the Detroit/Windsor area and in Kansas and Oklahoma (TRIGGER 1976, p. 820-25, GARRAD 2014, p. 499-523). One of the member nations of the confederacy, the Tahontaenrat, negotiated to join the Seneca, in present-day New York, where they established the town of Gandougarae (TRIGGER 1976, p. 828).

Kathryn Labelle's (2013) recent historical work addresses the post-relocation era based mainly on historical sources. The subject has garnered almost no archaeological interest, and it is worth considering the reasons for this. To some degree, the reasons may lie in the nature of the archaeological record. Unlike pre-relocation sites, which included large, palisaded villages, these post-relocation settlements were occupied for shorter periods of time. They are fewer in number and not geographically connected or circumscribed within a small region. Furthermore, the people who created these sites were ethnically diverse, because the Wendat had joined with the Tionnontaté and the Odawa. While European settlers accidentally encountered many Wendat villages in Huronia, this was not the case in the areas occupied by post-relocation Wendat in the Upper Great Lakes. Thus, the cultural landscapes of the post-relocation Wendat are not recognized as such, the region being seen instead as wilderness, or a modern version of terra nullius (Dent, 2013). However, as John Creese (2015) points out, these sites exist and are interesting from the vantage point of resiliency. To ignore them, and to ignore the postdispersal history, is to contribute to the myth that the Wendat and Wyandot disappeared or were destroyed. The archaeology of the postrelocation period has potential to contribute to our understanding of how people experienced and negotiated population-level movement. This is a question that could not be more relevant today. 


\section{Researching Ancestors}

One of the most sensitive research areas for Indigenous peoples, and one which has changed considerably in recent years, pertains to the excavation and study of buried human ancestors. The reasons for the sensitivity are deeply rooted in Huron-Wendat beliefs. One of the souls of a person remains with the bones of the deceased. In the words of Georges Sioui (1999: 142), "Contact between the living and the dead was not severed by death." Bones, then, are people. They are not simply organic remains of individuals to be viewed as specimens worthy of scientific examination. Many HuronWendat ossuaries have been disturbed and some have been desecrated over the past two centuries. Andrew Hunter describes in detail disturbance to ossuaries that occurred in the mid-nineteenth century (Hunter, 1902), but ossuaries continue to be accidentally discovered and disturbed into the twenty-first century. During the twentieth century, a number of Huron-Wendat ossuaries were excavated, and the bones were subject to numerous academic studies (e.g., Forrest, 2010; Gruspier, 1998; Jerkic, 1975). Historically, communication about the findings of these studies to the Huron-Wendat Nation was minimal: in 2005, Wendat elder Annette Vincent explained to one of us (AH) that the archaeologists had had the bones for a long time and done nothing with them and that the time had arrived to return the ancestors to where they came from (Annette Vincent, personal communication , 2005). We have, however, seen significant improvements in the treatment of human ancestors and communication about them in the course of the past 15 years.

\section{Beginning with Ossossané}

In 1946, an avocational archaeologist, Frank Ridley, (re)discovered an ossuary that he believed fit the description of the Ossossané ossuary where Jean de Brébeuf witnessed the Wendat feast of the dead in 1636 (Ridley, 1947). Over the course of two field seasons, staff from the Royal Ontario Museum excavated this ossuary (Kidd, 1953). While a number of ossuaries had been discovered and excavated prior to 1948, these were informal excavations, sometimes carried out by local curiosity seekers. The excavation of Ossossané was one of the first academically oriented excavations, and this kind 
of excavation continued in Simcoe County and southern Ontario until the Ontario Heritage Act (1974) was enacted in 1975. Subsequently, ossuaries have been excavated, but only in the context of development work, when they have been encountered accidentally during construction or trenching (Keenleyside, 2013; Williamson \& Pfeiffer, 2003). While some of these ossuaries have been moved, the Huron-Wendat Nation has indicated by a resolution dating from 2015 that from now on, in the unfortunate event that ancestors' bones are encountered accidentally, the burial ground will not be moved and development must be rerouted.

The ancestors' bones and accompanying funerary items from Ossossané were studied by a number of scholars after 1948, but it would appear that these findings were not effectively shared with the Huron-Wendat descendants (Kapches, 2010). In the late 1990s, after lobbying by descendants from Wendake, the Royal Ontario Museum entered into an agreement with the Huron-Wendat Nation to repatriate the ancestors and funerary materials from Ossossané (Kapches, 2010). The 1999 repatriation can be seen as pivotal for two reasons: first, it marked the first time in 350 years that Huron-Wendat and Wyandot from across Canada and the United States had come together to participate in ceremonies in their seventeenth-century homeland (Labelle, 2013). The event brought together long-separated relatives who would go on to participate in future conferences, events, and projects, thereby strengthening connections between communities. Second, it set the stage for future repatriations. It would be disingenuous to suggest that all archaeologists and anthropologists in Ontario were, at the time, in agreement with the return of the Huron-Wendat ancestors. With time, however, those opposed have come to a clearer understanding of the position of the Huron-Wendat and Wyandot with respect to their ancestors, and most now accept that repatriation is the correct thing to do.

In 2013, after years of planning, a second large repatriation (known as the Thonnakona repatriation) was carried out, involving more than 1600 Huron-Wendat ancestors. Like the Ossossané repatriation, the Thonnakona repatriation was a complex process, as was documented by two of the people who spearheaded it: Susan Pfeiffer and Louis Lesage (Pfeiffer \& Lesage, 2014). One significant difference between the Ossossané repatriation and the Thonnakona 
repatriation is that, researchers asked and, after careful consideration, the Huron-Wendat agreed to place one tooth from each individual and samples of diseased bone in a repository at the University of Toronto for future study. The Huron-Wendat made this decision based on the premise that they believed the ancestors would be willing to make the gift of a tooth if it would contribute to knowledge about their people and to help their descendants to better understand their lives and times. The change in the practice of study is indicated by the fact that these teeth can only be studied through an application process to the Huron-Wendat Nation (Pfeiffer \& Lesage, 2014).

The research that Dr. Susan Pfeiffer and her colleagues presented at the conference based on these tissue samples was of a high degree of interest to Huron-Wendat and Wyandot participants, as evidenced by the excellent attendance at her early morning presentation and by the request of the Huron-Wendat to include this presentation specifically in the Web summaries. To date, the work of Pfeiffer and her colleagues has focussed on diet and age of weaning; but ongoing analyses will focus on genetic ancestry and health (Pfeiffer, 2015; Pfeiffer et al. 2016, 2017).

The Huron-Wendat are now preparing for the reburial of many other groups of ancestors in the coming years, including many hundreds of individuals who are conserved in government ministries, museums, and universities, or with licensed archaeologists and private corporations. It will probably take a generation to rebury all the ancestors that have been exhumed during the past hundred years. This is the duty that the present generation of Huron-Wendat descendants has accepted out of respect for the souls of the ancestors who are still living in these bones. The negotiation of agreements such as the one between the University of Toronto and the HuronWendat Nation leaves open the possibility of future studies of these ancestors, but places the decision making about the questions to be addressed and the nature of the analysis in the hands of the members of the Huron-Wendat Nation. 


\section{Conclusions: Challenges and Opportunities}

The examples that we have outlined demonstrate that archaeologists, who have been the self-appointed and, later, government-mandated "custodians" of Indigenous heritage (Ferris, 2003), including that of the Huron-Wendat, may find themselves in uncomfortable or unfamiliar positions. The challenges that arise through dialogue between the Huron-Wendat Nation and archaeologists also present opportunities for researchers. They have the potential to contribute meaningfully, not only to archaeological bodies of knowledge and methodologies, but also to Huron-Wendat and Wyandot communities. Widely accepted culture-historical classificatory categories, such as "St. Lawrence Iroquoian," may have little validity in the eyes of Huron-Wendat descendants who see ethnicity in a different way than do archaeologists. Archaeologists are asked, then, to think more carefully about what these constructs represent, and to assess how the use of them may impact people today. Archaeological research is pushed to move beyond identification of small differences in ceramic styles - the reasons for which are not well understood. Researchers are called upon to use multiple lines of evidence, including oral traditions, archives, and historical and linguistic documents, in describing the past. Work on the post-relocation Huron-Wendat and Wyandot past will entail tackling low-visibility, multi-ethnic sites that are disconnected in space but are important for understanding Huron-Wendat and Wyandot resilience. Research on human ancestors is providing results about changing diet, among other things, and researchers are challenged to (a) ensure that research questions are relevant to HuronWendat and Wyandot people and (b) employ minimally destructive analysis techniques to allow for future research.

We argue that, while these research directions may mean shedding some deeply held ideas, collaborative partnerships in which descendant communities such as the Huron-Wendat Nation set the research agendas ultimately lead to work that is relevant to communities and that is carried out in a fashion that is culturally appropriate and acceptable to descendants. 


\section{Acknowledgements}

We thank Allison Bain and Réginald Auger for inviting us to participate in the session "What Does Heritage Change: Case Studies in Archaeology" at the meetings of the Association of Critical Heritage Studies. We thank Kathryn Sampeck for insightful comments on an earlier draft of this paper. Finally, we extend our gratitude to the Huron-Wendat Nation of Wendake, Québec, for allowing us to work on their ancestral lands and archaeological sites, which contribute to better understanding their past and building relationships towards collaborations.

\section{Bibliography}

ATALAY, S. Indigenous Archaeology as Decolonizing Practice. The American Indian Quarterly, vol. 30, n. 3, 2006, p. 280-310.

BARBEAU, M. Huron and Wyandot Mythology. Ottawa: Department of Mines, Geological Survey, Government Printing Bureau, 1915.

BARBEAU, M. Huron-Wyandot Traditional Narratives in Translations and Native Texts. Ottawa: Department of Northern Affairs and National Resources, National Museum of Canada, 1960.

BIGGAR, H. P. The Works of Samuel de Champlain. Toronto: Champlain Society, 1936.

BLACKBURN, C. Harvest of Souls: The Jesuit Missions and Colonialism in North America 1632-1650. Montreal and Kingston: McGill-Queen's University Press, 2000.

CHRISOMALIS, S. \& TRIGGER, B.G. Reconstructing Prehistoric Ethnicity: Problems and Possiblities. In WRIGHT, J. V. \& PILON, J.L. (Org.), A Passion for the Past: Papers in Honour of James F. Pendergast. Gatineau: Canadian Museum of Civilization, 2004, p. 419-434. 
COBB, C. R. Archaeology and the "Savage Slot": Displacement and Emplacement in the Premodern World. American Anthropologist, vol. 107, n. 4, 2005, p. 563-573.

COLWELL, C. How the Archaeological Review Behind the Dakota Access Pipeline Went Wrong. The Conversation. Retrieved from http://theconversation.com/how-the-archaeological-review-behindthe-dakota-access-pipeline-went-wrong-67815, 2016.

CREESE, J. Archaeology of the Wendat Diaspora. Presentation to the Ontario Archaeological Society, Midland, Ontario, 2015.

DENT, J. False Frontiers: Archaeology and the Myth of the Canadian Wilderness. Totem: The University of Western Ontario Journal of Anthropology, vol. 21, n. 1, 2013, p. 59-71.

EDMUNDS, D. S., R. SHELBY, A. JAMES, L. STEELE, M. BAKER, Y.V. PEREZ \& K. TALLBEAR. Tribal Housing, Codesign, and Cultural Sovereignty. Science, Technology and Human Values, vol. 38, n.6, 2013, p. 801-828.

FERRIS, N. Between Colonial and Indigenous Archaeologies: Legal and Extra-legal Ownership of the Archaeological Past in North America. Canadian Journal of Archaeology/Journal Canadien d'Archéologie, vol. 27, n. 2, 2003, p. 154-190.

FERRIS, N. Being Iroquoian, Being Iroquois: A Thousand-year Heritage of Becoming. In N. FERRIS, R. HARRISON \& M.V. WILCOX (eds.), Rethinking Colonial Pasts Through Archaeology. Oxford: Oxford University Press, 2014, p. 371-396.

FORREST, C. Iroquoian Infant Mortality and Juvenile Growth, 1250 to 1700 AD. Ph.D. Dissertation, University of Toronto, 2010.

GATES ST-PIERRE, C. Iroquoians in the St. Lawrence River Valley before European Contact. Ontario Archaeology, n. 96, 2016, p. 4764.

GARRAD, C. Petun to Wyandot: The Ontario Petun from the Sixteenth Century. Gatineau: Canadian Museum of History and University of Ottawa Press, 2014. 
GAUDREAU, M. \& L. LESAGE. Understanding Ethnicity and Cultural Affiliation: Huron-Wendat and Anthropological Perspectives. Ontario Archaeology, n. 96, 2016, p. 6-16.

GLENCROSS, B., G. WARRICK, E. EASTAUGH, A. HAWKINS, L. HODGETTS \& L. LESAGE. Minimally Invasive Research Strategies in Huron-Wendat Archaeology. Advances in Archaeological Practice, vol. 5, n. 2, 2017, p. 147-158.

GRUSPIER, K. Subadult Growth and Health from Ossuary Samples of Prehistoric Southern Ontario Iroquoian Populations. Ph.D. Dissertation, University of Toronto, 1998.

Heidenreich, C. E. Huronia, A History and Geography of the Huron Indians 1600-1650. Toronto: McClelland and Stewart Limited, 1971.

HUNTER, A. F. Notes of sites of Huron villages in the township of Tiny (Simcoe County) and adjacent parts prepared with a view to the identification of those villages visited and described by Champlain and the early missionaries. Toronto: Warwick Bros. and Rutter, 1899.

HUNTER, A. F. Notes on Sites of Huron Villages in the Township of Medonte (Simcoe Co.). Toronto: Warwick Bros. \& Rutter, 1902.

HUNTER, A. F. Notes on Sites of Indian Villages, Townships of North and South Orillia. Toronto: Warwick Bros. \& Rutter, 1904.

HUNTER, A. F. Huron Village Sites (Including Surveys of Flos and Vespra Townships). Annual Archaeological Report, Appendix to the Report of the Minister of Education, Ontario, 1906, p. 3-56, 1907.

IPINCH. Community-Based Cultural Heritage Research. Retrieved January 12, 2018, from https://www.sfu.ca/ipinch/projectcomponents/working-groups/community-based-cultural-heritageresearch-cbchr-working-group/ 2016.

JAMIESON, J. B. The Archaeology of the St. Lawrence Iroquoians. In C. J. ELLIS \& N. FERRIS (eds.). The Archaeology of Southern Ontario to A.D. 1650. London, Ontario: London Chapter of the Ontario Archaeological Society, 1990, p. 385-404.

JERKIC, S. An analysis of Huron skeletal biology and mortuary practices: The Maurice Ossuary. Ph.D. Dissertation, University of Toronto, 1975. 
JOHNSTON, R. B., \& L. JACKSON. Settlement Pattern at the Le Caron Site, a 17th Century Huron Village. Journal of Field Archaeology, vol. 7, n. 2, 1980, p. 173-199.

JONES, A. E. "Sendake Ehen" or Old Huronia. Toronto: L. K. Cameron, 1908.

JURY, W. W. St. Ignace II. Canadian Catholic Historical Association Report, n. 14, 1946, p. 15-27.

JURY, W. W., \& E. M. JURY. Sainte-Marie among the Hurons. Toronto: Oxford University Press, 1954.

JURY, W. W., \& E. M. JURY. Saint Louis: Huron Indian village and Jesuit mission site. Bulletin of the Museum of Indian Archaeology, $\mathrm{n}$. 6, 1955.

KAPCHES, M. Ossossané Ossuary: The Circle Closes. Archaeology of Eastern North America, n. 38, 2010, p. 1-16.

KAPCHES, M. Transcription of J.C. Taché's 1866 Letter to Francis Parkman. Arch Notes, vol. 19, n.4, 2014, p. 5-8.

KEENLEYSIDE, A. Skeletal Evidence of Health and Disease among Iroquoians. In: M. K. MUNSON, \& S. M. JAMIESON (eds.). Before Ontario: The Archaeology of a Province. Montreal and Kingston: McGill-Queen's University Press, 2013, p. 177-187.

KIDD, K. E. The Excavation of Sainte-Marie I. Toronto: University of Toronto Press, 1949.

KIDD, K. E. The excavation and historical identification of a Huron ossuary. American Antiquity, n. 43, 1953, p. 359-379.

LABELLE, K. M. Dispersed but not Destroyed: A History of the Seventeenth Century Wendat People. Vancouver: UBC Press, 2013.

MACCALLUM FRASER, C., \& L. VISWANATHAN. The Crown Duty to Consult and Ontario Municipal-First Nations Relations: Lessons Learned from the Red Hill Valley Parkway Project. Canadian Journal of Urban Research, vol. 22, n.1, 2013, p. 1-19.

NAHRGANG, K. An Aboriginal Perspective. In: M. K. MUNSON \& S. M. JAMIESON, (eds.). Before Ontario: The Archaeology of a 
Province. Montreal and Kingston: McGill-Queen's University Press, 2013, p. 203-211.

MINISTRY OF TOURISM AND CULTURE. Engaging Aboriginal Communities: A Draft Technical Bulletin for Consultant Archaeologists in Ontario. 2010. http://www.mtc.gov.on.ca/en/publications/AbEngageBulletin.pdf

PFEIFFER, S. New Discoveries about the Lives of Wendat Ancestors. Presentation to the Ontario Archaeological Society, Midland, Ontario, 2015.

PFEIFFER, S., \& L. LESAGE. The Repatriation of Wendat Ancestors, 2013. Canadian Journal of Archaeology, n. 38, 2014, p. $5-12$.

PFEIFFER, S., J.C. SEALY, R. F. WILLIAMSON, C. FORREST \& L. LESAGE. Patterns of Weaning among Ancestral Huron-Wendat Communities, Determined from Nitrogen Isotopes. American Antiquity, vol. 82, n. 2, 2017, p. 244-261.

PFEIFFER, S., J.C. SEALY, R.F. WILLIAMSON, S. NEEDSHOWARTH \& L. LESAGE. Maize, Fish, and Deer: Investigating Dietary Staples Among Ancestral Huron-Wendat Villages, As Documented from Tooth Samples. American Antiquity, vol. 81, n. 3, 2016, p. 515-532.

RAMSDEN, P. The Current State of Huron Archaeology. Northeast Anthropology, n. 51, 1996, p. 101-112.

RAMSDEN, P. Becoming Wendat: Negotiating a New Identity around Balsam Lake in the Late Sixteenth Century. Ontario Archaeology, n. 96, 2016a, p. 121-132.

RAMSDEN, P. The Use of Style in Resistance, Politics and the Negotiation of Identity: St. Lawrence Iroquoians in a Huron-Wendat Community. Canadian Journal of Archaeology, n. 40, 2016b, p. 122.

RICHARD, J.-F. Territorial Precedence in Eighteenth- and Nineteenth-Century Huron-Wendat Oral Tradition. Ontario Archaeology, n. 96, 2016, p. 26-34. 
RIDLEY, F. A. Search for Ossossane and Its Environs. Ontario History, n. 39, 1947, p. 7-14.

RIDLEY, F. A Report to the Archaeological and Historic Sites Advisory Board of the Government of Ontario, on a Survey of Indian Archaeological Sites in the year 1972. Toronto, 1972.

RIDLEY, F. Report to the Archaeological and Historic Board of the Government of Ontario, on a survey of Indian Archaeological Sites in the year 1973. Toronto, 1973.

RIDLEY, F. A Report to the Archaeological and Historic Sites Advisory Board of the Government of Ontario, on a Survey of Indian Archaeological Sites in the year 1968. Toronto: Ministry of Culture and Communications, 1975.

SAGARD, G. The Long Journey to the Country of the Hurons. Toronto: Champlain Society, 1939.

SILLIMAN, S. W. Collaborative Indigenous Archaeology: Troweling at the Edges, Eyeing the Centre. In SILLIMAN, S. W. (Org.) Collaborating at the Trowel's Edge: Teaching and Learning in Indigenous Archaeology. Tucson: The University of Arizona Press, 2008, p. 1-21.

SIOUI, G. E. Huron-Wendat: The Heritage of the Circle. Vancouver Lansing: UBC Press \& Michigan State University, 1999.

STECKLEY, J. St. Lawrence Iroquoians among the Wendat: Linguistic Evidence. Ontario Archaeology, n. 96, 2016, p. 17-25.

THWAITES, R. G. The Jesuit Relations and Allied Documents. Cleveland: Burrows Bros. Co., 1896-1902.

TOOKER, E. An Ethnography of the Huron Indians, 1615-1649 (Second edition). Syracuse: Syracuse University Press, [1964] 1991.

TREMBLAY, R. The St. Lawrence Iroquoians: Corn People. Montréal: Pointe-à-Callière, Montréal Museum of Archaeology and History, 2006.

TRIGGER, B. G. The Children of Aataenstsic: A History of the Huron People to 1660. Kingston: McGill-Queen's University Press, 1976. 
TRIGGER, B. G. Alternative Archaeologies: Nationalist, Colonialist, Imperialist. Man, n. 19(3), 1984, p. 355-370.

TRIGGER, B. G. Natives and Newcomers: Canada's "Heroic Age" Reconsidered. Montreal and Kingston: McGill-Queen's University Press, 1985.

TRIGGER, B. G. The Huron: Farmers of the North (Second edition). Fort Worth: Holt, Rinehart and Winston, 1990.

TRIGGER, B. G. The Liberation of Wendake. Ontario Archaeology, n. 72, 2001, p. 3-14.

WARRICK, G. A European infectious disease and the depopulation of the Wendat-Tionontate (Huron-Petun). World Archaeology, n. 35(2), 2003, p. 258-275.

WARRICK, G. A. A population history of the Huron-Petun, A.D. 500-1650. New York: Cambridge University Press, 2008.

WARRICK, G., \& LESAGE, L. The Huron-Wendat and the St. Lawrence Iroquoians: New Findings of a Close Relationship. Ontario Archaeology, p. 96, 2016, n. 133-143.

WILLIAMSON, R. F. East-West Interaction among FifteenthCentury St. Lawrence Iroquoian and North Shore of Lake Ontario Ancestral Wendat Communities. Ontario Archaeology, n. 96, p. 104120. 2016.

WILLIAMSON, R. F., \& PFEIFFER, S., Org. Bones of the Ancestors: The Archaeology and Osteobiography of the Moatfield Ossuary. Gatineau, Quebec: Canadian Museum of Civilization Mercury Series, 2003.

WRIGHT, J. V. The Conquest Theory of the Ontario Iroquois Tradition: A Reassessment. Ontario Archaeology, n. 54, p. 3-15, 1992.

RECEBIDO EM: 01/06/2018 APROVADO EM: 12/07/2018 